\title{
Modal Sosial Dan Strategi Alternatif Penanganan Konflik Masyarakat
}

\author{
Andy Arya Maulana Wijaya dan Sry Mayunita \\ Fakultas Ilmu Sosial dan Ilmu Politik Universitas Muhammadiyah Buton \\ Email: bulawambona.87@gmail.com
}

\begin{abstract}
Abstrak, Penelitian ini ditujukan untuk mengkaji korelasi antara modal sosial dan konflik sosial yang mendasasi terjadinya kasus pembusuran di Kota Baubau. Kasus ini cukup meresahkan masyarakat karena pelaku adalah pelajar di Kota Baubau. Kajian dilakukan melalui pendekatan modal sosial, sehingga memungkinkan untuk melakukan pengamatan terhadap masalah perilaku pelajar sebagai pelaku pembusuran dalam kelompok sosialnya. Kajian ini menemukan bahwa, komponen modal sosial yakni kepercayaan, norma sosial dan kerjasama dalam lingkungan sosial pelaku pembusuran berlangsung tertutup, dalam artian hanya sebatas pada kelompoknya saja. Hal ini berlaku oleh karena, beberapa factor yang mendasari munculnya perilaku pembusuran di kalangan pelajar yakni, pertama; konflik antar lingkungan yang terus berulang, kedua; lingkungan pertemanan yang terpilah oleh konflik, ketiga; kurangnya interaksi positif dengan orang tua dan guru di sekolah, keempat; terdapat dendam yang diwariskan dan menjadi acuan pelajar dalam lingkungan pergaulannya.
\end{abstract}

\section{Kata Kunci: Modal Sosial, Konflik Sosial, Pelajar}

Abstract, This research is intended to examine the correlation between social capital and social conflict which has led to the occurrence of eviction cases in Baubau City. This case is quite disturbing because the perpetrators are students in the city of Baubau. The study was carried out through a social capital approach, making it possible to observe student behavior problems as perpetrators of evictions in their social groups. This study found that, the component of social capital, namely trust, social norms and cooperation in the social environment, the perpetrators of the evictions were closed, in the sense that they were limited to the group. This applies because, several factors underlie the emergence of eviction behavior among students namely, first; recurring inter-environmental conflicts, second; friendship environment that is divided by conflict, third; lack of positive interactions with parents and teachers at school, fourth; there is a revenge that is inherited and becomes a reference for students in their social environment.

Keywords: Social Capital, Social Conflict, Student 


\section{Pendahuluan}

Indonesia darurat kekerasan anak, baik anak sebagai korban maupun anak sebagai pelaku kejahatan meningkat. Data yang dirilis oleh Komisi Perlindungan Anak Indonesia (KPAI) tahun 2015, menunjukkan adanya kenaikan jumlah anak sebagai pelaku dalam kasus kejahatan yang semakin meningkat, dan sebaliknya anak menjadi korban kasus kekerasan menurun. Kecenderungan turunnya kasus anak sebagai korban menunjukkan kesadaran orang tua dan lembaga pendidikan terhadap isu perlindungan anak, tetapi sisi lain tingginya anak sebagai pelaku kekerasan menunjukkan adanya factor lingkungan yang tidak kondusif bagi perlindungan anak (www.kpai.go.id/berita, diakses Maret 2017 Pukul 09.07)

Masih berdasar pada data KPAI 2015, penurunan anak sebagai korban kekerasan mencapai 147 kasus, angka tersebut turun jika dibandingkan pada tahun 2014 dengan 159 kasus. Fenomena ini kemudian berubah, yang semula anak-anak menjadi korban maka kini justru sebaliknya, anak-anaklah yang menjadi pelaku kekerasan. Motif dari hal tersebut bisa berbeda-beda, hanya saja hal ini cukup disayangkan karena penyimpangan tersebut dilakukan oleh anak-anak.

Demikian halnya, kasus anak sebagai pelaku kekerasan juga terjadi di Kota Baubau Sulawesi Tenggara. Dalam portal berita online Kabarbuton.com tertanggal 18 Desember 2016, mengangkat judul berita Pelaku Pembusuran di Baubau Didominasi Pelajar. Pemberitaan ini, adalah akumulasi dari beberapa kasus sebelumnya yang mana kasus pembusuran yang terjadi di Kota Baubau, justru banyak melibatkan pelaku yang masih usia pelajar yakni usia 10-14 Tahun. Busur atau paporo dalam istilah lokal, merupakan alat yang dibuat serupa anak panah dengan ketapel sebagai pelemparnya, busur memang dikenal sebagai senjata tajam dan seringkali digunakan pada konflik antar warga, karena ujungnya yang tajam, seringkali busur dapat menelan korban jiwa.

Bahkan hingga kini, Kota Baubau masih berhadapan dengan beberapa kasus kriminal lainnya, dan ini membuat kenyamanan warga sedikit terganggu. Khusus pada pembusuran oleh pelaku usia anak-anak (remaja) ini, disinyalir pertama kali mencuat pada beberapa waktu lalu (Pertengahan tahun2016). Fenomena ini diduga terjadi oleh karena, terus berulangnya konflik antar warga di dua wilayah Kota Baubau dan beberapa wilayah lainnya.

Tercatat, pada tahun 2016 adanya pengungkapan kasus pelaku pembususran dan pembuat busur yang berhasil diamankan oleh Polres Baubau dengan kategori dewasa sudah dilakukan proses hukum oleh Satreskim Polres Baubau dan Polsek Wolio sebanyak 4 orang dan sebanyak 9 orang masih dibawah umur dan dikembalikan kepada orang tuanya untuk dibina (tribratapoldasultra.com, 2016). Kasus ini menjadi persoalan dimasyarakat dan menjadikan sejumlah pihak resah adalah bukan karena terulangnya konflik 
namun keterlibatan anak-anak atau pelajar di dalamnya.

Tidak ada informasi yang cukup jelas mengenai asal muasal terjadinya perilaku kriminalitas pembusuran oleh pelajar di Kota Baubau. hanya saja, dalam teori kelas yang menyatakan bahwa setiap perilaku tidak hanya dianalisis pada satu aspek kejadian saja, namun kemudian kasus saling terhubung dengan kondisi lainnya. Meskipun demikian, hal yang lebih penting adalah bahwa tidak masalah bagaimana kita mendefinisikan sebuah fenomena namun mustahil mempelajarinya secara terisolasi tanpa meneliti lebih jauh relasinya dengan fenomena-fenomena yang lain. untuk kasus pembusuran oleh pelajar ini, kita dapat mempelajarinya dalam ruang terbuka dari adanya pengaruh masalah lainnya. Untuk itu, dalam kajian sosial hal ini dapat dipertautkan dengan relasi kelas dalam masyarakat, dan kelas seperti juga modal, adalah sebuah relasi bukan "barang" (Thompson, 1963; dalam Klinken dan Berenschot, 2016).

Begitupun dengan kasus pembusuran oleh anak-anak di Kota Baubau, boleh jadi konflik horizontal antar kelompok masyarakat di Kota Baubau yang seringkali terulang dan menimbulkan korban jiwa, menjadi jalinan yang saling terhubung untuk menjelaskan fenomena kasus pembusuran di Kota Baubau. Terdapat dua daerah yang dinyatakan rawan terjadinya konflik warga, yakni kelompok warga wilayah kelurahan Bone-Bone, Tarafu dan Wameo. Meski demikian, beberapa wilayah lainnya seringkali pula terjadi konflik warga, namun dari sejumlah pelaku yang ditemui dalam penelitian ini masih begitu terhubung dengan tiga lokasi diatas jika dilihat dari tempat tinggal para pelaku yang menjadi responden dalam kajian ini.

Dengan melihat relasi tersebut diatas, kajian ini mencoba menelusuri keterlibatan lingkungan sosial sebagai salah satu akar masalah atau bisa jadi motif yang timbul dari perilaku kriminal pembusuran oleh pelajar. Kajian modal sosial digunakan sebagai nilai yang tengah menjadi focus utama, dimana modal sosial dikaji dalam bentuk saling percaya (trust), norma sosial (norms) dan jaringan sosial (network). Masing-masing nilai tersebut akan dikaji karakteristiknya pada latarbelakang pelaku, kemudian dapat digunakan pula sebagai upaya mencari cara penanganan kasus pembusuran di kalangan pelajar di Kota Baubau.

\section{Metode Penelitian}

Pemilihan Lokasi Penelitian ini dilakukan berdasarkan pada wilayah konsetrasi terjadinya konflik masyarakat,berdasarkan hal itupula penelitian pada kalangan pelajar ditujukan pada beberapa pelajar yang tercatat di Kepolisian Resort Baubau sebagai pelaku yang bertempat tinggal di lokasi konflik tersebut. Penelitian akan mengkaji keterkaitan situasi sosial yakni tempat tinggal dan masyarakat sekitar para pelajar pelaku pembusuran, sehingga didapati sebab terjadinya perilaku kriminal oleh pelajar tersebut.

Penelitian dilakukan dengan model deskriptifkualitatif, dalam pengumpulan data 
sampel ditentukan melalui pusposivesampel melalui responden terpilih, yang kemudian dilakukan dengan melakukan wawancara mendalam terhadap pelaku pembusuran yang terkategori, yakni pelaku pembuat busur, tertangkap membawa busur dan tertangkap karena didakwa menggunakan busur untuk melukai orang lain. Selain itu, sampel dibantu melalui metode snowballsampling untuk memungkinkan memperoleh lebih banyak fakta lingkungan sosial anak-anak/ pelajar pelaku pembusuran.

\section{Hasil Penelitian dan Pembahasan}

a. Pendekatan Modal Sosial Untuk Memahami Struktur Masyarakat

Modal sosial bukanlah barang ataupun kepemilikan materi, namun sesuatu yang kemudian tumbuh dan berkembang pada kehidupan sosial individu. Modal sosial mengarahkan individu dalam kelompok sosialnya untuk dapat berkerjasama dan mengembangkan diri, termasuk adalah menjadi sarana untuk menciptkan konsensus bersama yang mana hal ini dapat mencegah terjadinya konflik sosial.Robert Putnam (1995; 65-78) mendefinisikan modal sosial sebagai "bentuk organisasi sosial seperti jejaring, norma dan tingkat kepercayaan sosial yang memungkinkan terjadinya koordinasi dan kerjasama yang saling menguntungkan".

Sebagaimana Francis Fukuyama (2010) mengungkapkan bahwa modal sosial dapat dipahami dalam dua bentuknya, yaitu; 1) modal sosial menunjuk pada kapabilitas yang muncul dari kepercayaan umum di dalam sebuah masyarakat atau bagian tertentu darinya; 2) modal sosial merupakan serangkaian nilai atau norma informal yang dimiliki bersama di antara anggota suatu kelompok yang memungkinkan terjadinya kerjasama di atara mereka.

Hubungan mengenai modal sosial terhadap kekerasan dan perilaku menyimpang, dijelaskan oleh Putnam (dalam Field, 2016)menjelaskan hubugan dalam level modal sosial yang tinggi di masyarakat, menjadi bukti bahwa level kejahatan yang cenderung lebih rendah. Halpern (dalam Field, 2016) telah menemukan bahwa lebih dari setengah perbedaan angka kejahatan yang dilaporkan dapat dijelaskan dengan perbedaan lintas bangsa dalam ketimpangan ekonomi, kepercayaan sosial, dan apa yang didefinisikan sebagai nilai "kepentingan diri". Dengan demikian, modal sosial dapat dipandang sebagai satu di antara sekian faktor yang membantu memengaruhi jumlah aktivitas kejahatan di dalam suatu komunitas (Field, 2016).

Modal sosial itu sifatnya produktif, dalam artian bahwa interaksi modal sosial memiliki capaian-capaian positif bagi perkembangan komunitas masyarakat jika kemudian dapat dimanfaatkan dengan maksimal. Meskipun interaksi terjadi karena berbagai alasan, orang-orang berinteraksi, berkomunikasi dan kemudian menjalin kerjasama pada dasarnya dipengaruhi oleh keinginan untuk berbagi cara mencapai tujuan bersama yang tidak jarang berbeda dengan tujuan dirinya sendiri secara pribadi. Keadaan ini terutama terjadi pada interaksi 
yang berlangsung relatif lama (Suharto, 2007: 98).

Terkait hal ini, Suharto menjelaskan kriteria menakar modal sosial dalam komunitas, yaitu ; (a) Kepercayaan, bahwa hal ini bisa menumbuhkan dan mempermudah pertukaran dan interaksi antar individu-individu, kelompokkelompok dan institusi-institusi. (c) norma, terdiri dari pemahaman, nilai, harapan dan tujuan yang ingin dicapai bersama kelompok/ komunitasnya. (b) Kerjasama, hal ini mengakui bahwa komunitas masyarakat seringkali tidak bisa menyediakan kepentingannya sendiri maka dengan melakukan kerjasama atau aktivitas kolektif untuk menanggulanginya.

Dalam mencermati konflik antar kelompok masyarakat yang mengatasnamakan wilayah tertentu seperti yang terjadi di Kota Baubau, bisa dilihat sebagai bentuk terkuat modal sosial pada kelompoknya, namun untuk konteks lebih luas yakni modal sosial masyarakat Kota Baubau secara umum, hal ini dapat dikatakan bahwa kondisi modal sosial melemah (Warren dalam Field, 2016). Begitupun kemudian hal ini memengaruhi kehidupan sosial anak-anak didalam komunitas itu, semisal kasus pembusuran oleh para pelajar tentunya ini tersebab adanya pengaruh dari sobeknya modal sosial masyarakat Kota Baubau secara umum, sehingga tingkat kepercayaan dalam kelompoknya lebih kuat daripada kepercayaan masyarakat secara umum.

Modal sosial memang menciptakan manfaat bagi individu dalam komunitas sosialnya, namun hal ini jika hanya merujuk pada faktor-faktor yang membantu individu dan kelompok bekerja sama untuk mencapai tujuan bersama. Akan tetapi, modal sosial juga dapat memunculkan hasil yang tidak diharapkan (Field, 2016). Modal sosial pun dapat menghasilkan keburukan sosial semisal konflik horizontal yang mengatasnamakan kelompok. Olehnya itu, modal sosial juga bisa dikatakan berada pada dualisme manfaat positif dan negative sekaligus. Fukuyama (2000) menyatakan tentang hal ini bahwa, Semakin luas radius kekuasaan menjangkau ke luar anggota kelompok, eksternalitas semakin menyenangkan dan positif, semakin radius kepercayaan dibatasi pada anggota kelompok sendiri, semakin besar kemungkinan eksternalitas negatifnya (dalam Field, 2016).

\section{b. Konflik Dalam Struktur Masyarakat}

Dalam proporsi masyarakat yang berbeda, sudah tentu berbeda kejadian konflik yang terjadi begitupun dengan unit analisis yang digunakan untuk mengkaji sebuah konflik sosial. Sejalan dengan pandangan Sanderson (2003) yang menekankan pada tiga komponen dasar dalam analisis system sosiokultural. Menurutnya, bahwa komponen-komponen dasar system sosiokultural terdiri atas; superstruktur ideologis, struktur sosial dan infrastruktur material. Ketiga komponen dasar inilah, yang kemudian dijadikan pijakan para sosiolog dalam menganalisis 
fenomena atau kejadian-kejadian sosial yang berlangsung.

Mencermati posisi konflik sosial yang kemudian "menular" ke komunitas pelajar di Kota Baubau dalam kajian ini, merujuk pada penjelasan Marx dan Turner (1998, dalam Sanderson, 2003) yang mengatakan bahwa mereka yang tersubordinasi akan menjadi peduli terhadap kepentingan kolektif mereka atas dominasi kelompok ordinat dengan mempertanyakan pola distribusi sumberdaya alam yang tidak merata tersebut. Akibatnya adalah rusaknya relasi disposisi aleanatif yang diciptakan oleh kelompok ordinat terhadap kelompok subordinat. Dalam kondisi seperti ini, kelompok subordinat membangun kesatuan ideology untuk mempertanyakan system yang berlangsung dan melakukan "perlawanan" melalui kepemimpinan kolektif terhadap kelompok ordinat. Hal inilah yang kemudian menyebabkan polarisasi antara kelompok ordinat dengan kelompok subordinat yang berkepanjangan (Sanderson, 2003).

\section{c. Profil Pelajar Pelaku Pembusuran}

Terdapat beberapa kategori keterlibatan anak terduga kasus pembusuran, begitupun penangkapan dan penahanan mereka berbeda-beda. Adapun kategori tersebut yaitu; Pertama: Pelajar pelaku pembuat busur, Kedua: Pelajar yang kedapatan membawa busur saat razia oleh kepolisian, Ketiga: Pelajar yang terbukti menggunakan busur untuk melukai orang lain (memiliki korban). Sekalipun usia mereka masih dalam kategori anak-anak, masih bersekolah dan juga berprestasi di kelasnya, namun urusan busur mereka begitu fasih bercerita tentang busur, pembuatannya dan bagaimana menggunakannya.

Pelajar pelaku pembusuran yang sempat diwawancarai dalam penelitian ini, berkisar pada umur 13 Tahun hingga 20 Tahun, masih aktif bersekolah mulai dari jenjang SMP dan SMA di Kota Baubau. Dalam lingkungan sekolah, mereka memiliki pertemanan yang erat pada beberapa orang di kelasnya. Dari semua pelaku, mampu menyebutkan pelajaran yang disenangi dan guru yang mereka senangi dalam kelas.

Sebut saja namanya AS, salah seorang responden dalam penelitian ini mengenai fenomena pembusuran di Kota Baubau. Ia berusia 13 tahun dan saat ini tercatat sebagai pelajar di salah satu Sekolah Menengah Pertama (SMP) Kota Baubau yang terletak di Jalan Betoambari. Duduk di kelas 8 (Kelas 2) dan menyenangi Pelajaran Ilmu Pengetahuan Sosial. AS berurusan dengan pihak kepolisian oleh karena pernah membuat busur, hanya karena ia masih di bawah umur maka penahanan dilakukan dengan mengembalikannya kepada pengawasan dan pembinaan orang tua ${ }^{1}$. Beberapa pelaku lainnya, di lakukan penahanan di kepolisian dengan durasi atau masa tahanan berbeda-beda.

Menariknya dari AS, ia anak yang berprestasi juara silat, selama mewawancarainya saya mendapatkan beberapa informasi. Sejak SD hingga SMP ia

\footnotetext{
${ }^{1}$ Wawancara bersama Kapolres Baubau, Bapak Suryo Aji
} 
seringkali mendapat beasiswa, selain itu saat SMP kelas 7 AS adalah juara 1 di kelasnya, olehnya itu saat kelas 8 AS di tempatkan di kelas unggulan. Sedangkan untuk prestasi di luar akademik atau sekolah, ia adalah Juara 1 Silat se- Kota Baubau 3 (tiga) kali berturut-turut, seringkali mewakili Kota Baubau di Kompetisi Silat Provinsi Sulawesi Tenggara.

Mencermati latarbelakang salah satu pelaku, memang tidak ada yang berhubungan langsung dan memungkinkan ia terlibat dalam kasus pembusuran. Motif pelaku dalam kepemilikan busur tersebut. Namun dalam kutipan wawancara salah seorang pelaku mengakui bahwa busur digunakannya untuk menjaga ayam peliharaanya dari pencuri ${ }^{2}$. Disisi lain, dia sendiri seringkali ikut terlibat dalam konflik atau tawuran pelajar antar sekolahnya dengan sekolah tetangganya, ia mengatakan biasanya tawuran terjadi jika ada yang memulai, intinya kalau pelajar sekolah sebelah memulai, maka mereka akan melawan begitu pula sebaliknya ${ }^{3}$. Dari pernyataan tersebut, boleh jadi kepemilikan busur didasari alasan menlindungi peliharaannya namun reaksinya terhadap insiden tawuran cenderung reaktif.

Begitupun dengan pelaku lainnya yang diwawancarai, sekalipun motif penangkapan mereka berbeda-beda, namun komentar terhadap reaksi mereka jika berada dalam situasi tawuran baik itu sekolahnya atau lingkungan tempat

\footnotetext{
${ }^{2}$ Wawancara bersama AS (13 Tahun) tinggal di Lorong Kehutanan

${ }^{3}$ ibid
}

tinggalnya, adalah ikut terlibat apapun bentuknya. Perasaan untuk ikut membela wilayahnya bisa jadi alasan untuk keberanian mereka terlibat, namun alasan kenapa mesti terlibat cenderung terbaikan oleh pelaku yang adalah pelajar tersebut. Hal ini tentu mengindikasikan bahwa lingkungan, memberikan motivasi mereka untuk terlibat.

Seperti misalnya, dari wawancara terhadap salah seorang pelaku yang menyatakan bahwa ia memiliki busur dengan cara membuatnya sendiri, sebagai caranya untuk jaga-jaga karena sebelumnya sepupunya menjadi korban konflik antara pemuda lingkungan kanakea dan lingkungan wameo ${ }^{4}$. Hubungan motivasi dan kondisi lingkungan terhadap perilaku kekerasan oleh pelajar, sejalan dengan pendapat Komisioner Komisi Perlindungan Anak Indonesia (KPAI) Susanto mengatakan, banyaknya kejahatan dan aksi kriminalitas yang dilakukan anak harus dilihat secara utuh, baik sebagai korban atau pelaku. Anak sebagai pelaku krimininalitas lebih banyak dipengaruhi faktor lingkungan yang tidak bersahabat, pengaruh media atau perlakuan teman sekelilingnya (kpai.go.id, 2014 diakses pada 19 Maret 2017; pukul 15.30).

Disisi lain, profil hubungan pelaku dengan keluarga, terutama ibu dan bapaknya cukup baik. Hanya saja, rata-rata mereka adalah anak-anak dari keluarga yang ibu dan bapaknya bekerja seharian penuh, sehingga intensitas dan komunikasi antara anak dan orang tua cenderung kurang intensif. Meski begitu, kebutuhan sehari-hari

\footnotetext{
${ }^{4}$ Wawancara bersama RA (17 Tahun) tinggal di Wameo
} 
dan sekolahanya cukup terpenuhi dari orang tuanya. Namun, semua pelaku saat diproses hukum oleh karena kasus pembusuran dan kepemilikan busur, orang tua tidak mengetahui anaknya memiliki, terlibat maupun membuat busur dirumahnya. Dari hal ini, dapat diindikasikan bahwa komunikasi yang intens terhadap aktivitasanak dalam keluarga kurang, sehingga informasi terkait aktivitas anaknya terabaikan.

Mencermati hal tersebut, tentunya faktor lingkungan secara langsung akan dapat menginspirasi anak utamanya pelajar untuk meniru. Tayangan televisi yang berisi pornografi, lalu games bernuasa kekerasan ikut berpengaruh pada perilaku anak. Anak melakukan dari apa yang mereka lihat, mereka rasakan(kpai.go.id, 2014 diakses pada 19 Maret 2017; pukul 15.30). Mengingat bahwa masyarakat Indonesia adalah pengguna internet terbesar di dunia, dengan jumlah pengguna internet sebanyak 132,7 Juta pada tahun 2016 (http://tekno.kompas.com,2016, diakses 19 Maret 2017 Pukul 15.30). Kondisi ini bisa memberi pengaruh cukup signifikan terhadap perilaku anak-anak atau pelajar, apalagi tanpa pengawasan dari keluarga dan sekolah, yang kemudian termotivasi terhadap lingkungan yang berkonflik.

Disaat komunikasi dan pengawasan sekolah dan keluarga yang jarang, anak-anak atau pelajar ini lebih banyak menghabiskan waktu untuk berselancar di internet, termasuk mengakses konten kekerasan semisal penggunaan busur, dan tentu saja beragam video tutorial cara membuat busur dengan sangat mudahnya. Seperti diungkapkan oleh dua orang pelaku, yang belajar membuat busur dari internet maupun melihat videonya di youtube ${ }^{5}$. Kemudian mereka membuatnya secara sembunyi-sembunyi di bengkel dekat rumah mereka, tentunya tanpa sepengetahuan orang tuanya ${ }^{6}$. Kembali lagi bahwa, factor lingkungan memungkinkan pelajar memperoleh informasi busur dan tindak kekerasan lainnya dengan begitu mudah.

Kondisi ini mendukung pernyataan oleh Soekanto (2007), masalah generasi muda pada umumnya ditandai oleh dua ciri yang berlawanan, yakni keinginan untuk melawan dan sikap apatis. Beberapa sikap melawan, misalnya, dalam bentuk radikalisme dan delinkuensi. Sedangkan sikap apatis seperti penyesuaian yang membabibuta terhadap ukuran moral.Kondisi ini bisa terjadi pula pada para pelaku pembusuran yang notabene adalah masih usia anak-anak dan remaja. Perilaku pelajar pelaku pembusuran tersebut tentu berlaku pada mereka, respon pelajar terhadap lingkungan bisa begitu reaktif atau apatis.

\section{d. Pendekatan Modal Sosial Untuk Penanganan Kasus Pembusuran}

Modal sosial dapat dipahami sebagai perspektif nilai yang dijadikan alat bagi sebuah komunitas yang mewujud dalam serangkaian interaksi dan aktivitas mereka. Dari adanya interaksi tersebut individu

\footnotetext{
${ }^{5}$ Wawancara dengan AS (13 Tahun) tinggal di Lorong Kehutanan dan RA (17 Tahun) Tinggal di Wameo

${ }^{6}$ Wawancara dengan RA (17 Tahun) tinggal di Wameo
} 
mampu membangun jaringan-jaringan yang menguntungkan bagi kepentingan kolektif mereka, jika di pertautkan dengan kasus pembusuran di Kota Baubau yang dilakukan oleh pelajar, maka perlu ditinjau pada konteksnya. Meski, kerjasama yang terjalin nampak begitu erat dan guyub, namun jika kerjasama tersebut dilakukan sebagai bentuk perlawanan terhadap kelompok lain tentu ini akan berdampak negatif secara umum. Hasbullah (2006: 22; dalam Sudarmo, 2008; 101-112) memaparkan mengenai jaringan-jaringan yang memperkuat modal sosial akan memudahkan saluran informasi dan ide dari luar yang merangsang perkembangan kelompok masyarakat.

Pemahaman mengenai pelajar dan kelompoknya, merupakan dua hal yang tidak terpisahkan sebagai kondisi psikologis yang berkembang di usia remaja. Oleh karena itu, penelitian ini mengkaji hubungan modal sosial dan perilaku pembusuran oleh pelajar di Kota Baubau. Hubungan fenomena tersebut dan modal sosial dapat diamati dalam pemahaman bahwa modal sosial dikaji sebagai bagian dari organisasi sosial, seperti kepercayaan, norma, dan jaringan, yang dapat memperbaiki efisiensi masyarakat dengan menfasilitasi tindakan terkoordinasi (Putnam; 1994 dalam Field; 2010). Dalam kajian Slamet (2010: 26) juga mengemukakan hal demikian, bahwa modal sosial tempatnya bukan dalam diri para tokoh melainkan dalam hubungan jaringan dalam suatu struktur sosial tertentu secara vertikal atau horizontal dikalangan para tokoh. Untuk memahami hal tersbut, berikut elemen modal sosial yang dikaitkan dengan upaya penanganan kasus pembusuran oleh pelajar;

\section{1) Kepercayaan}

Perasaan saling percaya bisa menumbuhkan dan mempermudah pertukaran dan interaksi antar individuindividu dalam kelompok sosialnya. Begitupun juga pada para pelaku pembusuran, dimana pada lingkungan pergaulan yang lebih luas dalam pengertian tidak terbatas hanya pada lingkungan kelurahan (tempat tinggalnya), terdapat kecenderungan untuk berhati-hati. Salah seorang pelaku pelaku pembusuran berasal dari kelurahan wameo, mengakui bahwa dia tetap menjalin pertemanan dengan teman sekolahnya yang berasal dari kanakea. Namun, perasaan hati-hati tetap ada dengan alasan bahwa perlu jaga-jaga jangan sampai mereka main belakang ${ }^{7}$. Busur dipilih, karena daya jangkaunya yang bisa dilakukan bahkan jika dari jarak jauh, informasi ini diperoleh mereka dari internet.

Dalam beberapa wawancara dengan pelaku lainnya, juga mengakui hal demikian bahwa sekalipun berteman di sekolah namun jika berasal dari kelurahan yang menjadi lawan dalam konflik, maka mereka cenderung hati-hati bahkan beberapa merasa perlu menganggapnya musuh dan tak perlu menjalin pertemanan, padahal masih satu sekolah. Bahkan, perihal dendam tersebut menjadi legalitas untuk membalaskan perlakuan yang diterima oleh temannya. Seperti yang di kemukakan oleh salah seorang pelaku AN, bahwa "Temanku

\footnotetext{
${ }^{7}$ Wawancara dengan RA (17 Tahun) tinggal di Wameo
} 
duluan yang dibusur. Makanya kita balas dendam. Temanku yang dibusur juga yang suruh kita untuk balas dendamkan8".

Dalam realitas sosial yang lebih luas, pelembagaan dendam ini memang tidak begitu tampak, hanya saja dendam bahwa kelurahan ini dan kelurahan itu bermusuhan memang disimpan dan dirawat dengan baik oleh anak-anak hingga orang dewasa. Sehingga hal ini memaksa rasa saling percaya masyarakat hanya pada kelompok kelurahannya saja, namun untuk komunitas yang lebih luas tidak begitu jelas bahkan hanya sekedarnya saja.

\section{2) Norma Sosial}

Norma sosial mewujud pada pemahaman bersama terhadap suatu hal, termasuk adalah streotip yang dibangun oleh masyarakat. Secara tidak langsung norma sosial yang terbangun menjadi tinjauan perilaku, seperti misalnya steotip terhadap beberapa kelurahan sebagai daerah "texas" atau rawan konflik, atau misalnya daerah yang orang-orangnya akan terus saling bermusuhan. Ini kemudian bertransformasi menjadi norma sosial yang terawat, akibatnya adalah masing-masing pihak berusaha memisahkan diri, bahkan pada kondisi tertentu membangun istilahistilah yang dapat memancing kemarahan.

Seperti yang terungkap dalam wawancara, melalui istilah-istilah yang disebutkan menjadi alasan kemarahan dan menjadi sebab melakukan pembalasan. Hal ini diungkapkan oleh YS yang mengatakan

\footnotetext{
${ }^{8}$ Wawancara dengan AN (15 Tahun) tinggal di Bataraguru
}

bahwamereka sering dipanggil-panggil dengan kata mantoa/anjing pas ketemu di jalan atau pas pulang sekolah, makanya kita sering marah ${ }^{9}$. Kondisi lain juga ditemui pada pengakuan AS yang bahkan hanya untuk membela komunitas kecil (teman sekolahnya), ia berani untuk melempar bapak gurunya jika menghalangi mereka membalas lemparan pelajar dari sekolah tetangganya ${ }^{10}$.

Sedangkan pelaku lainnya mengaku bahwa mengetahui perihal pelarangan memiliki busur, namun dengan dalih hanya iseng mereka menyimpan busur dan membawanya kemana-mana. Situasi ini, dilatarbelakangi untuk membekali diri di jalan. Mencermati hal ini, dapat di indikasikan bahwa mereka mengetahui konsekuensi memiliki busur namun terpaksa harus melanggar norma sosial tersebut, karena menjaga diri di jalan lebih penting daripada hukuman yang diterimanya terhadap kepemilikan busur. Lingkungan yang tidak begitu bersahabat lebih dikhwatirkan, ketimbang konsekuensi hukum yang dapat diterimanya. Sedangkan lingkungan sosial, lebih menerima perbedaan sebagai pemisah, ketimbang merawat perbedaan untuk mencari persamaan.

\section{3) Kerjasama}

Ada dua model kerjasama, yakni kerjasama yang mengantarkan pada

\footnotetext{
${ }^{9}$ Wawancara dengan YS (16 Tahun) Tinggal di Bataraguru

${ }^{10}$ Wawancara dengan AS (13 Tahun) Tinggal di Lorong Kehutanan
} 
kebaikan bersama dan kerjasama yang mengantarkan pada kebaikan hanya pada kelompoknya saja. Dalam pembuatan hingga penggunaan busur oleh pelajar, selalu tidak dilakukan sendiri namun bekerjasama secara berkelompok. Hal ini ditemui pada semua pelajar pelaku pembusuran, mereka mengakui bahwa ketika membuat, menyimpan hingga merahasiakannya tidak dilakukan sendiri. Hanya saja mereka cenderung tertutup untuk mengakuinya saat wawancara dilakukan.

Dalam observasi yang dilakukan, baik terhadap lingkungan pergaulan pelaku dan lingkungan tempat tinggal pelaku. Masih terdapat saling menutup informasi, tergantung konteks atau pihak mana yang diminta berkomentar. Misalnya informasi tentang pelaku yang berasal dari kelurahan bone-bone, maka informan dari kelurahan bone-bone akan cenderung hati-hati menjawab, sedangkan informan dari kelurahan tarafu yang menjadi lawannya akan begitu banyak informasi yang diperoleh. Bahkan untuk beberapa hal yang berhubungan dengan asal mula konflik saling bertentangan ditemukan.

Mencermati kondisi ini, kerjasama individu dalam masyarakat boleh jadi baikbaik saja. Namun, kerjasama tersebut tidak membuka peluang adanya kerjasama dengan pihak atau komunitas lainnya. Sehingga dialog antara dua kelurahan ini tentu tidak menemukan solusi yang benarbenar solutif. Hal ini, tentu berimplikasi dari memori kolektif masyarakat yang ada terutama anak-anak atau dalam kajian ini adalah pelajar.

Dari beberapa penjelasan mengenai keterkaitan pendekatan modal sosial terhadap kasus pembusuran oleh pelajar yang terjadi di Kota Baubau, setidaknya kita dapat memetakan unsure-unsur modal sosial dalam sejumlah kasus pembusuran oleh pelajar di Kota Baubau. Adapun tipologi modal sosial fenomena tersebut pada tabel 1 ;

Tabel 1 
Tipologi Modal Sosial terhadap Kondisi Lingkungan Sosial Pelaku Pembusuran

\begin{tabular}{|c|c|l|}
\hline No. & $\begin{array}{c}\text { Komponen Modal } \\
\text { Sosial }\end{array}$ & \multicolumn{1}{|c|}{ Kondisi Sosial Pelaku Pembusuran } \\
\hline 1. & Kepercayaan & $\begin{array}{l}\text { Kepercayaan cenderung tertutup hanya pada sesama } \\
\text { kelompoknya (bisa jadi hanya sebatas kelurahan tempat } \\
\text { tinggal dan lingkup sekolah yang sama), sehingga } \\
\text { memungkinkan pada pelaku untuk menyimpan dendam } \\
\text { bahwa mereka yang bukan dari kelompoknya adalah } \\
\text { musuh, dan busur menjadi senjata untuk melindungi diri. }\end{array}$ \\
\hline 2. & $\begin{array}{l}\text { Adanya streotipe yang dipelihara, yang menyatakan bahwa } \\
\text { kelurahan A dan Kelurahan B saling bermusuhan. Sehingga } \\
\text { hal ini menjadi norma sosial dalam pergaulan. Untuk itu, } \\
\text { hal sekecil apapun yang terjadi diantara masyarakat atau } \\
\text { dalam hal ini pelajar yang berasal dari daerah itu bisa } \\
\text { menjadi pemicu kemarahan. }\end{array}$ \\
\hline 3. & $\begin{array}{l}\text { Kerjasama cenderung bersifat elitis, dalam artian hanya } \\
\text { pada kelompoknya saja. Oleh karenya, pada beberapa } \\
\text { kondisi masyarakat saling memelihara situasi saling } \\
\text { bermusuhan, hal ini turut mempengaruhi pelajar dari } \\
\text { daerah tersebut untuk menjaga diri. }\end{array}$ \\
\hline
\end{tabular}

Sumber: Analisis Data

Mencermati kondisi tersebut terhadap perilaku kekerasan pembusuran yang dilakukan oleh pelajar, setidaknya kajian ini mendapati beberapa temuan yang melatarbelakangi pelajar untuk terlibat kasus pembusuran tersebut;

1. Secara umum, pelajar bukan saja pelaku namun juga korban. Dimana motivasi untuk membuat dan memiliki busur tidak didasari oleh keinginan sendiri. Akan tetapi kondisi lingkungan sosialnya yang seringkali menunjukkan konflik yang bersifat lokalitas (antar kelurahan). Memaksanya mereka untuk memiliki busur, sudah barang tentu ketika memilikinya maka keinginan untuk menggunakannya hanya menunggu waktunya saja yang biasanya terjadi saat konflik berulang.

2. Lingkungan pertemanan terpilah-pilah, sekalipun hal ini tidak begitu nampak terlihat namun jejaring pertemanan pelaku dengan teman-teman sekolahnya cenderung memperhatikan lingkungan dimana mereka tinggal. Beberapa pelaku mengakui bahwa lingkungan kelurahan yang seringkali berkonflik, menjadi pertimbangan mereka untuk menjalin pertemanan apalagi jika dia berasal dari wilayah tersebut dan memiliki teman sekolah berasal dari wilayah yang menjadi lawannya dalam konflik. Pelajar yang juga menjadi pelaku pembusuran, 
mengungkapkan cenderung berhatihati terhadap temannya itu.

3. Kurangnya pengawasan orang tua memungkinkan mereka untuk leluasa membuat, memiliki maupun berinteraksi dengan lingkungan sosialnya yang lekat dengan konflik dan kepemilikan busur. Lingkungan sekolah pun, tidak begitu menjadi sarana pembelajaran moral tingkat kedua setelah rumah. Karena beberapa pelaku, justru terdorong untuk melindungi diri dari sekolah sebelahnya, rivalitas negatif ini menjadi rahasia umum yang terus "terjaga" bahwa konflik antar sekolah tersebut akan terus ada, dan ini dilakukan pula turun temurun oleh lingkungan sekolahnya, sehingga busur menjadi salah satu alternative untuk melindungi diri.

4. Adanya dendam yang diwariskan dari lingkungan sosial yang terus berkonflik dan berulang. Hal ini mengingat, lokasi tempat tinggal pelajar yang terjerat kasus pembusuran berasal dari daerah-daerah yang seringkali ditemui terjadi konflik semisal kelurahan BoneBone, Tarafu, Wameo, Kanakea, Bataraguru dan sebagainya. Bahkan dalam beberapa observasi ditemukan bahwa, sematan daerah "texas" untuk beberapa wilayah ini sudah menjadi streotipe yang terus melekat. Ini tentu berimbas pada motivasi para pelajar untuk menjadikan atau memposisikan dirinya menjadi bagian dari lingkungan yang sejatinya memiliki efek negative.

\section{Kesimpulan}

Kajian ini bahwa tidak ada perilaku yang tidak berlatar belakang pada motivasi tertentu. Paling tidak, ada "alasan tertentu" yang membuat perilaku tersebut terjadi. Apalagi sejumlah kasus ini dilakukan oleh pelajar yang masih berusia antara 13-20 Tahun. Boleh jadi, ada lingkungan sosial yang membentuk dan lingkungan sekolah yang mempengaruhinya. Untuk itu, pendekatan modal sosial yang hidup dalam komunitas memberikan penjelasan mengenai hal ini pada beberapa factor yang menjadi sebab munculnya perilaku tersebut, yakni ;

1. Konflik antar lingkungan yang member pengaruh kepada pelajar untuk mencari tahu dan terlibat.

2. Lingkungan pertemanan yang terpilah-pilah, oleh karena lingkungan tempat tinggal mereka berkonflik satu sama lain. dengan alasan melindungi diri, busur menjadi pilihan karena daya jangkaunya yang bisa dari jarak jauh.

3. Kurangnya pengawasan orang tua dan guru disekolah, hal ini mengakibatkan terbatasnya pengasuhan yang dilakukan orang tua yang seharian harus bekerja. Semua pelajar pelaku pembusuran, tidak ditahu oleh orang tuanya bahwa mereka memiliki dan bisa membuat busur, selama ini perilaku mereka normal.

4. Terdapat dendam yang "diwariskan", konflik antar kelurahan yang 
seringkali terjadi menjadi acuan para pelajar yang terlibat kasus pembusuran ini memposisikan dirinya yang lebih tertutup dalam pergaulan yang lebih luas.

\section{Daftar Pustaka}

Field, John. (2016). Cet.IV., Modal Sosial, Bandung: Kreasi Wacana.

Fukuyama, Francis. (2010). Trust: Kebijakan Sosial dan Penciptaan Kemakmuran, Yogyakarta: Penerbit Qalam.

Klinken, Gerry van dan Ward Berenschot. (2016). In Search Middle Indonesia; Kelas Mengenah di Kota-Kota Menengah. Jakarta: Buku Obor dan KITLV.

Landesang, Yager. (2014). Analisis Modal Sosial Pada Komunitas Anak Jalanan di Pasar Pagi Kota Samarinda Kalimantan Timur, e-Journal Ilmu Sosiatri 2014, 2(2):41-45, Samarinda: Fisip Universitas Mulawarman.

Sanderson, SK. (2003). Makros Sosiologi: Sebuah Pendekatan Terhadap Realitas Sosial (edisi kedua), Jakarta: PT Raja Grafindo Persada.

Slamet, Yulius. (2012)., Modal Sosial dan Kemiskinan, Surakarta: UNS Press.

Soerjono, Soekanto. (2007). Sosiologi Suatu Pengantar. Jakarta: PT Raja Grafindo.

Sudarmo. (2008). Social Capital untuk Community Governance, Jurnal Spirit Publik, Volume 4, Nomor 2 Halaman 101-112.

Suharto, Edi, (2011)., Kebijakan Sosial Sebagai Kebijakan Publik, Bandung: Alfabeta. 